\title{
Registered Nurses' Self-Assessment of Their Clinical Leadership Knowledge and Competence
}

\author{
Valerie Wright, DNP, MSN, RN \\ Walden University, Minneapolis, Minnesota, United States \\ Diane Whitehead, EdD, DNP, RN, ANEF \\ Walden University, Minneapolis, Minnesota, United States \\ Corinne Romano, DNP, MSN, RN \\ Walden University, Minneapolis, Minnesota, United States
}

Contact: $\underline{\text { mstrejour@aol.com }}$

\begin{abstract}
Clinical nurses play an important role in the healthcare team. The practice question for this Doctor of Nursing Practice project explored the perceptions of RNs about their clinical leadership knowledge and competencies at a 160-bed rehabilitation hospital in a metropolitan city in the southeast United States. Thirty RNs completed the following three surveys: an 8-question clinical leadership knowledge assessment, a 17-question leadership competency assessment, and a 6-question emotional intelligence self-assessment. Fifty percent or more of clinical nurses believed that they were knowledgeable in identified components of clinical leadership. The leadership competency skills assessment revealed a wide range: from $3-6 \%$ of participants who indicated that they were not at all competent to $33-57 \%$ of participants who indicated that they felt very competent. Seventy-six percent of the participants felt positive about their emotional intelligence abilities.

Recommendations to nursing leadership included workshops for clinical staff RNs on the various components of the Academy of Medical-Surgical Nurses' model of clinical leadership: clinical practice, environment practice, emotional intelligence, and leadership competencies.
\end{abstract}

Keywords: clinical nurse leadership; clinical nurse leader; staff nurse clinical leadership

Date Submitted: June 1, 2020 | Date Published: August 20, 2020

\section{Recommended Citation}

Wright, V., Whitehead, D., \& Romano, C. (2020). Registered nurses' self-assessment of their clinical leadership knowledge and competence. Journal of Excellence in Nursing and Healthcare Practice, 2, 17-23.

https://doi.org/10.5590/JENHP.2020.2.1.02

\section{Introduction}

Clinical nurses are an important component of the healthcare workforce and play a vital role in reducing costs and promoting quality patient outcomes (Grindel, 2016). Clinical nurse leaders can provide the necessary leadership at the point of care to enhance safe, quality care throughout the healthcare experience. Clinical leadership has been identified as impacting the clinical care environment, impacting safe, quality care, job satisfaction and nurse retention (Boamah, 2018; Mianda, 2018). Clinical nurse leaders are experts who help facilitate care that supports 
not only the patients but the staff as well (Grindel, 2016; Rankin, 2015). The Institute of Medicine (IOM) (2011) report, The Future of Nursing: Leading Change, Advancing Health, emphasizes that strong nursing leadership is necessary to improve patient safety outcomes and that the nursing profession must enhance its leadership role in health care redesign. Clinical leadership can be defined as putting clinicians at the soul of running healthcare clinical services in order to deliver exceptional outcomes for patients and populations (Abraham, 2011).

We conducted this quality improvement DNP project at a 160-bed rehabilitation hospital in a metropolitan city in the southeast United States. The nursing leadership sought assistance in exploring clinical leadership behaviors of

RNs at the bedside. For this project, clinical staff RNs were defined as RNs providing direct patient care, who might supervise other members of the healthcare team, such as licensed practical nurses or nursing assistants.

Understanding how clinical nurses perceive their leadership knowledge and competencies can provide nurse leaders and executives with a starting point for a clinical leadership education program at the facility.

\section{Background}

According to recent literature, nurses are hesitant to assume leadership roles in their practice environment because they feel a lack of knowledge, too busy, or disempowered (Grindel, 2016). A 2017 systematic review exploring the literature on clinical leadership revealed that clinical leaders demonstrate clinical competence, effective communication, an ability to motivate others, and a focus on excellence in nursing practice (Stanley \& Stanley, 2017).

Implementation of professional leadership programs for RNs at the bedside have demonstrated an increase in the leadership skills, communication skills, and interdisciplinary collaboration of clinical staff registered nurses (RNs) (Abraham, 2011; Abraham et al., 2013; Bender et al., 2016; Fardellone et al., 2014; Leigh et al., 2014). The target facility sought to enhance the leadership behaviors of RNs at the bedside.

\section{Theoretical Framework}

The Academy of Medical-Surgical Nurses (AMSN) task force of clinical and leadership experts developed a model of the core knowledge for clinical leadership (Grindel, 2016). The model supports the importance of essential knowledge and skills for clinical leaders at the bedside and consists of four components: clinical practice, environment practice, emotional intelligence and leadership competencies. Measures of quality such as national patient safety goals, core measures, measures of variance and cost reduction are emphasized. An ability to communicate and collaborate effectively as well as self awareness are important qualities for the clinical nurse leader (Grindel).

\section{Purpose}

The purpose of this project was to assess the staff RNs' perceptions of their competence in and knowledge about clinical leadership. The practice question was: What are the perceptions of staff RNs about their clinical leadership knowledge and competencies at this facility?

\section{Setting}

The setting for this DNP project was a 160-bed rehabilitation hospital in a metropolitan city in the southeast United States. 
Wright et al., 2020

\section{Participants}

We invited the full-time and part-time staff clinical RNs at the facility to participate in this project at their weekly staff meeting. Thirty-five RNs attended the staff meeting. Thirty RNs remained in the meeting room after the staff meeting to complete the surveys.

\section{Ethical Considerations}

A letter of cooperation was obtained from the facility and submitted to the Walden University Institutional Review Board (IRB). Approval to complete the project was obtained from the Walden University IRB (Approval No. 10-23-19-0229312). Participants signed a consent to participate prior to completing the surveys.

\section{Program Design}

The survey packet consisted of the 8-question AMSN Clinical Leadership Knowledge Assessment Form, the 17-question AMSN Leadership Competency Skills Survey and a 6-question Emotional Intelligence Questionnaire. The first two surveys were developed by a task force of clinical and leadership experts from the AMSN (Grindel, 2016). Through a series of discussions and rank ordering of topics, the core knowledge and competencies for clinical leadership were identified; the surveys were then developed (Grindel). Permission to use the surveys was obtained from AMSN. We developed the emotional intelligence survey from the discussion of norms that create an awareness of emotions from the Druskat and Wolff publication (2001) on building the emotional intelligence of groups. The survey packets were prepared in sealed envelopes and included the invitation and consent to participate and surveys. No identifying information other than a survey number was placed on the surveys. Participants placed the surveys in a secured drop box in the room. The survey box was picked up by the DNP student as soon as all participants were out of the room.

\section{Data Analysis and Results}

Descriptive statistics using SPSS were used to analyze the survey results. Results of these surveys revealed a wide variety of perceptions of competence and knowledge. Table 1 displays the statements and results from the 8-question clinical leadership knowledge form. For the category not at all knowledgeable, 30\% of the respondents indicated that they were not at all knowledgeable for cost drivers for nursing services. The majority of responses in this category for the other selections ranged from $3 \%$ to $16 \%$. 
Table 1: Clinical Leadership Knowledge, $N=30$

\begin{tabular}{|c|c|c|c|c|c|}
\hline & Statement & $\begin{array}{c}1=\text { Not At All } \\
\text { Knowledgeable }\end{array}$ & $\begin{array}{c}2=\text { Somewhat } \\
\text { Knowledgeable }\end{array}$ & $\begin{array}{c}3= \\
\text { Knowledgeable }\end{array}$ & $\begin{array}{c}4=\text { Very } \\
\text { Knowledgeable }\end{array}$ \\
\hline 1. & Quality Initiative & $4(13 \%)$ & $6(20 \%)$ & $12(40 \%)$ & $8(27 \%)$ \\
\hline 2. & $\begin{array}{l}\text { National Patient } \\
\text { Safety Goals }\end{array}$ & $1(3 \%)$ & $2(6 \%)$ & $13(44 \%)$ & $14(47 \%)$ \\
\hline 3 . & $\begin{array}{l}\text { Core Measurement } \\
\text { and HCAHPS }\end{array}$ & $3(10 \%)$ & $8(27 \%)$ & $10(33 \%)$ & $9(30 \%)$ \\
\hline 4. & $\begin{array}{l}\text { Reduction in Practice } \\
\text { Variations }\end{array}$ & $5(16 \%)$ & $6(20 \%)$ & $13(44 \%)$ & $6(20 \%)$ \\
\hline 5 . & $\begin{array}{l}\text { Critical Evaluation of } \\
\text { the Literature }\end{array}$ & $5(16 \%)$ & $6(20 \%)$ & $16(54 \%)$ & $3(10 \%)$ \\
\hline 6. & Hospital Systems & $5(16 \%)$ & $7(24 \%)$ & $12(40 \%)$ & $6(20 \%)$ \\
\hline 7 . & $\begin{array}{l}\text { Cost drivers for } \\
\text { Nursing Services }\end{array}$ & $9(30 \%)$ & $7(24 \%)$ & $9(30 \%)$ & $5(16 \%)$ \\
\hline 8. & $\begin{array}{l}\text { Health Practice } \\
\text { Environments }\end{array}$ & $2(6 \%)$ & $6(20 \%)$ & $13(44 \%)$ & \\
\hline
\end{tabular}

From "Clinical Leadership: A Call to Action" in C. G. Grindel, 2019, Medsurg Nursing: Official Journal of the Academy of Medical-Surgical Nurses, 25(1), 9-16. Used with permission of the Academy of Medical-Surgical Nurses (AMSN).

The statements identified for the emotional intelligence survey were taken from the discussion of individual norms in Druskat and Wolff (2001). Responses from the 6-question emotional intelligence assessment survey revealed that at least $76 \%$ of the participants responded yes to all the questions with $100 \%$ of the respondents indicating that they felt they were able to read other individuals' feelings and behaviors. Table 2 depicts the questions on the emotional intelligence assessment and survey results.

Table 2: Emotional Intelligence Assessment $\mathrm{N}=30$

\begin{tabular}{|c|c|c|}
\hline Question & Yes & No \\
\hline 1. Are you able to read other individuals' feelings and behaviors? & $30(100 \%)$ & o (o\%) \\
\hline $\begin{array}{l}\text { 2. Are you able to look beyond the behavior to recognize hidden } \\
\text { motivations and agendas? }\end{array}$ & $27(90 \%)$ & $3(10 \%)$ \\
\hline $\begin{array}{l}\text { 3. When you experience strong emotions (fear, anger), do you later reflect } \\
\text { on the situation that led to the emotion? }\end{array}$ & $23(76 \%)$ & $7(24 \%)$ \\
\hline $\begin{array}{l}\text { 4. When you experience strong emotions (fear, anger), do you behave and } \\
\text { speak appropriately? }\end{array}$ & $25(83 \%)$ & $5(17 \%)$ \\
\hline $\begin{array}{l}\text { 5. When you experience strong emotions (fear, anger), do you stay on } \\
\text { task? }\end{array}$ & $29(97 \%)$ & $1(3 \%)$ \\
\hline $\begin{array}{l}\text { 6. When you experience strong emotions (fear, anger), are you able to } \\
\text { separate the cause of the emotion (another person) from that emotion? }\end{array}$ & $24(80 \%)$ & $6(20 \%)$ \\
\hline
\end{tabular}

Adapted from "Building the Emotional Intelligence of Groups" by V. Druskat \& S. Wolff, 2001, Harvard Business Review, 79(3), 81-90. 
Responses to the 17-question assessment on leadership competency skills revealed a wide range of selfassessment. In 6 of the 17 items on emotional intelligence assessment, 3-6\% of participants responded that they were not at all competent. For somewhat competent, 3-27\% of the participants responded competent. For competent, $23-50 \%$ of participants responded feeling competent. For the final selection, very competent, $33-57 \%$ of participants responded feeling very competent. Table 3 displays the components of the skills survey and participant responses. Responses were scored as yes or no and percentage of responses calculated.

Table 3: Leadership Competency Skills $N=30$

\begin{tabular}{|c|c|c|c|c|}
\hline Statements & $\begin{array}{l}1=\text { Not At All } \\
\text { Competent }\end{array}$ & $\begin{array}{c}2= \\
\text { Somewhat } \\
\text { Competent }\end{array}$ & $\begin{array}{c}3= \\
\text { Competent }\end{array}$ & $\begin{array}{c}4=\text { Very } \\
\text { Competent }\end{array}$ \\
\hline 1. Using emotional intelligence & o (o\%) & $1(4 \%)$ & $10(33 \%)$ & $19(63 \%)$ \\
\hline 2. Coaching/mentoring colleagues & $1(3 \%)$ & $2(6 \%)$ & $11(37 \%)$ & $16(54 \%)$ \\
\hline $\begin{array}{l}\text { 3. Educating patients, families, and } \\
\text { colleagues }\end{array}$ & o (o\%) & $1(3 \%)$ & $10(34 \%)$ & $19(63 \%)$ \\
\hline 4. Resolving conflict & o (o\%) & $3(10 \%)$ & $15(50 \%)$ & $12(40 \%)$ \\
\hline $\begin{array}{l}\text { 5. Defusing lateral violence/bullying in } \\
\text { the workplace }\end{array}$ & $\mathrm{o}(0 \%)$ & $4(13 \%)$ & $12(40 \%)$ & $14(47 \%)$ \\
\hline $\begin{array}{l}\text { 6. Addressing a colleague who was not } \\
\text { doing a procedure correctly }\end{array}$ & $2(6 \%)$ & $3(10 \%)$ & $9(30 \%)$ & $16(54 \%)$ \\
\hline $\begin{array}{l}\text { 7. Collaborating with nurses re: patient } \\
\text { care issue }\end{array}$ & o (o\%) & $1(3 \%)$ & $7(23 \%)$ & $22(74 \%)$ \\
\hline $\begin{array}{l}\text { 8. Calling together an interprofessional } \\
\text { team to discuss a patient care issue }\end{array}$ & $1(3 \%)$ & $3(10 \%)$ & $8(27 \%)$ & $18(60 \%)$ \\
\hline $\begin{array}{l}\text { 9. Calling together an interprofessional } \\
\text { team to discuss a workflow issue }\end{array}$ & $1(3 \%)$ & $3(10 \%)$ & $8(27 \%)$ & $18(60 \%)$ \\
\hline 10. Leading teams/committees & $2(6 \%)$ & $3(10 \%)$ & $8(27 \%)$ & $17(57 \%)$ \\
\hline 11. Leading teams/committee meetings & $2(6 \%)$ & $8(27 \%)$ & $10(33 \%)$ & $10(33 \%)$ \\
\hline $\begin{array}{l}\text { 12. Preparing for team/committee } \\
\text { meetings }\end{array}$ & o (o\%) & $5(17 \%)$ & $15(50 \%)$ & $10(33 \%)$ \\
\hline 13. Initiating a change initiative & $1(3 \%)$ & $5(17 \%)$ & $7(23 \%)$ & $17(57 \%)$ \\
\hline 14. Leading a change initiative & $1(3 \%)$ & $6(20 \%)$ & $11(37 \%)$ & $12(40 \%)$ \\
\hline $\begin{array}{l}\text { 15. Presenting clinical updates to } \\
\text { colleagues }\end{array}$ & $2(6 \%)$ & $3(10 \%)$ & $13(44 \%)$ & $12(40 \%)$ \\
\hline $\begin{array}{l}\text { 16. Presenting information at a } \\
\text { team/committee meeting }\end{array}$ & $2(6 \%)$ & $5(17 \%)$ & $11(37 \%)$ & $12(40 \%)$ \\
\hline $\begin{array}{l}\text { 17. Presenting at a professional } \\
\text { conference }\end{array}$ & $5(17 \%)$ & $6(20 \%)$ & $10(33 \%)$ & $9(30 \%)$ \\
\hline
\end{tabular}

From "Clinical Leadership: A Call to Action" in C. G. Grindel, 2019, Medsurg Nursing: Official Journal of the Academy of Medical-Surgical Nurses, 25(1), 9-16. Used with permission of the Academy of Medical-Surgical Nurses (AMSN). 


\section{Recommendations}

Results of these surveys revealed a wide variety of perceptions of competence and knowledge.

Recommendations to nursing leadership included development of workshops for clinical staff RNs on the various components of the AMSN model of clinical leadership four components of clinical practice, environment practice, and emotional intelligence and leadership competencies. A second recommendation was to enhance the existing clinical ladder program to support clinical leader knowledge and skills through a clinical leadership development program including topics related to leadership in clinical practice, environment management, and emotional intelligence. A clinical ladder initiative could ensure that all levels of clinical nurses have an opportunity to improve their leadership knowledge and competence.

\section{Strengths and Limitations}

Thirty out of the 35 clinical RNs participated in this project. This allowed the optimal RN participation for the surveys. An existing clinical ladder program could be adapted to include clinical leadership education activities. The facility is currently applying for Magnet certification. Nursing leadership is highly supportive of staff nurse development and eager to follow through on clinical nurse leadership development. Limitations included a onetime assessment of clinical staff and no opportunity for obtaining any qualitative data through interviews, focus groups, or written comments. Some interesting qualifiers for this project would have been to connect level of education, certifications, and participation in the facility's clinical ladder program.

\section{Future Applications}

This project informed the facility of the importance of building on clinical leadership knowledge and skills from the beginning of a nursing career. Assessing new point-of-care employees related to their perceived clinical leadership knowledge and skills would allow employees to create professional goals based on their assessment. An annual individual development plan focusing on clinical leadership would help to reinforce the importance of this role to the organization. As noted in the AMSN model, organizational commitment to clinical leadership is imperative for clinical leaders to perform. This project underscored the importance of leadership awareness as a first step in developing clinical nurse leaders. 


\section{References}

Abraham, P. J. (2011). Developing nurse leaders: a program enhancing staff nurse leadership skills and professionalism. Nursing Administration Quarterly, 35(4), 306-312.

https://journals.lww.com/naqjournal/Abstract/2011/10000/Developing_Nurse_Leaders_A_Progr am Enhancing.5.aspx

Abraham, P., Burnette, A., Wannarka, E., \& Weerheim, L. (2013). Nursing excellence: Leadership opportunities promote staff nurse growth and development. Nurse Leader, 11(6), 61-64. http://doi: https://doi.org/10.1016/j.mnl.2013.07.012

Bender, M., Williams, M., Wei, S., \& Hites, L. (2016). Clinical nurse leader integrated care delivery to improve care quality: Factors influencing perceived success. Journal of Nursing Scholarship, 48(4), 414-422. https://doi.org/10.1111/jnu.12217

Boamah, S. (2018). Linking nurses' clinical leadership to patient care quality: The role of transformational leadership and workplace empowerment. Canadian Journal of Nursing Research, 5o(1), 9-19. https://doi.org/10.1177/0844562117732490

Druskat, V. \& Wolff, S. (2001). Building the emotional intelligence of groups. Harvard Business Review, 79(3), 81-90. https://hbr.org/2001/03/building-the-emotional-intelligence-of-groups

Fardellone, C., Smith, E., Musil, C. M., \& Click, E. R. (2014). Leadership behaviors of frontline staff RNs. Journal of Continuing Education in Nursing, 45(11), 506-513. https://doi.org/10.3928/0022012420141023-05

Grindel, C. G. (2016). Clinical leadership: A call to action. Medsurg Nursing: Official Journal of the Academy of Medical-Surgical Nurses, 25(1), 9-16.

Institute of Medicine (US) Committee on the Robert Wood Johnson Foundation Initiative on the Future of Nursing. (2011). The future of nursing: Leading change, advancing health. National Academies Press.

Leigh, J. A., Wild, J., Hynes, C., Wells, S., Kurien, A., Rutherford, J., Rosen, L., Ashcroft, T., \& Hartley, A. (2015). Transforming community services through the use of a multidimensional model of clinical leadership. Journal of Clinical Nursing, 24(5-6), 749-760. https://doi.org/10.1111/jocn.12668

Mianda, S., \& Voce, A. (2018). Developing and evaluating clinical leadership interventions for frontline healthcare providers: a review of the literature. BMC health services research, 18(1), 747. https://doi.org/10.1186/s12913-018-3561-4

Rankin, V. (2015). Clinical nurse leader: A role for the 21st century. Medsurg Nursing, Official Journal of the Academy of Medical-Surgical Nurses 24(3), 199.

Stanley, D., \& Stanley, K. (2018). Clinical leadership and nursing explored: A literature search. Journal of Clinical Nursing, 27(9-10), 1730-1743. https://doi.org/10.1111/jocn.14145

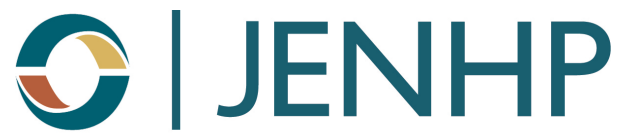

The Journal of Excellence in Nursing and Healthcare

Practice welcomes manuscripts focusing on topics such as national and international workforce issues, quality improvement projects, evidence-based practice initiatives, nursing research studies, interprofessional practice, educational issues, telehealth, improvements in technology, and the impact of social change in society. 